\title{
Article
}

\section{The emergence of international food safety standards and guidelines: understanding the current landscape through a historical approach}

Ramsingh, Brigit

Available at http://clok.uclan.ac.uk/13626/

Ramsingh, Brigit ORCID: 0000-0001-7551-4370 (2014) The emergence of international food safety standards and guidelines: understanding the current landscape through a historical approach. Perspectives in Public Health, 134 (4). pp. 206-215. ISSN 1757-9139

It is advisable to refer to the publisher's version if you intend to cite from the work. http://dx.doi.org/10.1177/1757913914536557

For more information about UCLan's research in this area go to http://www.uclan.ac.uk/researchgroups/ and search for <name of research Group>.

For information about Research generally at UCLan please go to http://www.uclan.ac.uk/research/

All outputs in CLoK are protected by Intellectual Property Rights law, including Copyright law. Copyright, IPR and Moral Rights for the works on this site are retained by the individual authors and/or other copyright owners. Terms and conditions for use of this material are defined in the policies page.

\section{CLoK}

Central Lancashire online Knowledge www.clok.uclan.ac.uk

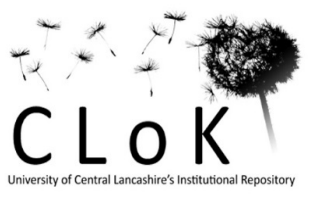




\title{
The Emergence of International Food Safety Standards and Guidelines: Understanding the current landscape through an historical approach.
}

\begin{abstract}
Following the Second World War, the Food and Agriculture Organization (FAO) and the World Health Organization (WHO) teamed up to construct an International Codex Alimentarius (or "food code") which emerged in 1963. The Codex Committee on Food Hygiene (CCFH) was charged with the task of developing microbial hygiene standards, although it found itself embroiled in debate with the WHO over the nature these standards should take. The WHO was increasingly relying upon the input of biometricians and especially the International Commission on Microbial Specifications for Foods (ICMSF) which had developed statistical sampling plans for determining the microbial counts in the final end-products. The $\mathrm{CCFH}$, however, was initially more focused on a 'qualitative' approach which looked at the entire food production system and developed codes of practice as well as more descriptive end-product specifications which the WHO argued were "not scientifically correct". Drawing upon historical archival material (correspondence and reports) from the WHO and FAO, this paper examines this debate over microbial hygiene standards and suggests that there are many lessons from history which could shed light upon current debates and efforts in international food safety management systems and approaches.
\end{abstract}

Key words: food safety, food hygiene, standards, Codex alimentarius, Codex Committee on Food Hygiene, Betty C. Hobbs, Food and Agriculture Organization (FAO), World Health Organization (WHO), International Commission on Microbial Specifications for Foods (ICMSF), United Nations, International Organization for Standardization (ISO), HACCP.

"The habit of licking the fingers to pick up paper or to turn over the pages of a book is a bad one at any time but particularly so when the paper, contaminated with saliva, is used for wrapping food."- Dr. Betty C. Hobbs, $1953 .{ }^{1}$ 
A surge of advice on food hygiene emerged in the postwar era when scientists and bureaucrats alike became involved in the process of trying to eliminate these threats to the food supply. Hygiene standards often took the material form of exhaustive lists, reports, charts, manuals, books and pamphlets - the precursors to today's electronic formats - which set limits on the maximum microbial counts permitted in the final product.

In addition to describing numerical limits and parameters, however, the standards would also advocate behavioural guidelines for anyone in contact with the food, for example control of hygiene habits of labourers who work in abbatoirs or prohibitions on the use of raw (e.g., unpasteurized) milk in cheese products. Dr. Betty Hobbs, a British bacteriologist and an internationally recognized authority on food poisoning and food hygiene, was just one of many experts doling out advice aimed at various audiences (Figure 1). Hobbs was one of the first members of the Public Health Laboratory Service in London, and became director of its Food Hygiene Laboratory. The FAO and WHO experts would draw upon the work of microbiologists like Hobbs in developing food safety standards starting in the 1960s, at a time when two different approaches to food hygiene were combining. One approach was to descriptively and qualitatively address behaviour and practices and infrastructure at all points along the food production continuum, for example, by reorganizing abbatoir layout, advocating the use of hair nets in factories, urging labourers to refrain from chewing gum or picking one's nose. The other approach involved the application of statistical methods to food safety problems, but mainly focusing quantitatively on the food product itself moreso than the entire food production continuum. Ultimately, both approaches were retained and blended together, but, as this paper will demonstrate, in the 1960s there was a clash within the Codex over these approaches, which showcases not only the different attitudes of the WHO and the FAO toward food hygiene, but also how these two 
approaches drew upon and placed emphasis on different forms of expertise, which had consequences for both health protection and the food industry.

This discussion had two key features. First, the distinction between standardizing practices versus standardizing the food object itself presented pragmatic problems of enforcement within member states as well as varying degrees of burden upon industry and public health systems and thus prompted the Codex Alimentarius Commission to differentiate between Standards for "End Products" versus "Codes of Practice" (compare Boxes 1 and 2 with Box 3). The second feature of this discussion is marked by a shift from more qualitative descriptions to include standards that emphasize numerical parameters and employ statistical data in order to be deemed "scientifically correct”. Implicit with this second feature is a contested meaning of safety and international endorsement of how to assess risk quantitatively. Through an historical analysis, it will be argued that food standards development represent a process of 'coproduction' - that is, standards can incorporate, represent and direct both the natural and social orders. The 'natural' order is that which is normally associated with the 'scientific' objective or rational knowledge, whereas the 'social' can come to mean a variety of "building blocks" - norms, politics, institutions, social practices, identity, culture, attitudes, values, beliefs. ${ }^{2}$ An examination of the Codex food hygiene committee's work demonstrates how the production and construction of standards based on microbiological science and statistical evidence involves a parallel construction and consideration of the social order (e.g. the practices and behaviours that ensure good hygiene). In the Codex, the two could not be separated and it became apparent through work on establishing hygiene standards and attempting to curb the presence of microbes in food, that there was a difference between standardizing the food items and standardizing the practices which bring about a desired end. There were economic, 
legal, social and political implications of conflating the two and this debate played out in the Codex Committee on Food Hygiene (CCFH) as discussed below.

Box 1. Example of "End Product Specification" from Food and Agriculture Organization, Report of the Sixth Session of the Codex Committee on Food Hygiene, May 1969.

"END-PRODUCT SPECIFICATIONS:

Appropriate methods should be used for sampling, analysis, and determination to meet the following specifications:

To the extent possible in good manufacturing practice the products should be free from objectionable matter. The products should not contain any pathogenic microorganisms or any toxic substances originating from microorganisms."

\section{BACKGROUND}

The meaning of food hygiene is historically contingent. Anne Hardy has made the historiographic distinction that there are two types of illnesses associated with food: 1) one associated with adulteration (e.g. deliberate contamination, addition of foreign substances like chemicals); versus 2) the illness caused by foods which had undergone decomposition, putrefaction or decay - the products of which were once thought of as chemical toxins and called "ptomaines" in the $19^{\text {th }} \mathrm{C}$, and said to be the cause "ptomaine poisoning". 3 Alongside these older frameworks of food adulteration and 
putrefaction, however, there also arose a growing awareness of the role of the microbe in making food unsafe, and by the late $19^{\text {th }} \mathrm{C}$ the term "food poisoning" emerged, with its implications of bacteria as causal agent. ${ }^{4}$

Bacteriology was entering its heyday in late $19^{\text {th }}$ and early $20^{\text {th }}$ centuries with the race to identify and classify newly discovered microbes. Once food poisoning began to emerge as a medical problem in the early part of the $20^{\text {th }} \mathrm{c}$, so too did the urge to set food hygiene standards. For example, in England the young medical officer William Savage called for bacteriological standards and hygiene standards as early as 1909, but the complexity of the problem made it difficult to know where to focus: the farms, the abbatoirs, the vendors, the consumers? And more importantly, which disciplines should be involved to address the problem: bacteriologists, veterinarians, of public health officers. ${ }^{5}$,

The end of the Second World War marked a watershed for food poisoning and food safety standards, and hygiene problems intensified for several reasons. The increased industrialization of the food system in the 1950s and 1960s brought about the appearance of large-sized "factory" farms, particularly in North America and Western Europe. These developments also meant that more food safety problems emerged as food travelled longer distances, and new technologies and hygiene measures were required to address these problems. ${ }^{7}$ For example, frozen foods, which prior to WWII were sold only at "high prices in low volumes in fragmented markets", became the fastest growing food sector in the United States by the 1950s. ${ }^{8}$ This increased scale and complexity of the food production system gave rise to greater incidence of Salmonellosis which was identified as a key concern in poultry and dairy sectors during this time (Figure 2). Moreover, increased reporting of foodborne illnesses and emergence of surveillance networks for problems like salmonellosis, increased focus on the health of developing populations by international agencies, and increased worldwide 
trade, all meant that the time was ripe for coordinated international efforts in establishing food standards.

One way to combat this problem of controlling the microbe was to eliminate any 'subjective' qualitative descriptions of the hygiene standards, especially in the final product specifications. Enlisting biometricians was one way to do so and this is where the differences in opinion over the standards emerged between the major players. Appealing to expert statistical knowledge is not novel; it has been well documented that statistical styles of reasoning had been occurring within pockets of scientific and medical research communities starting in the early and throughout the $19^{\text {th }}$ century. ${ }^{9},{ }^{10},{ }^{11}$ Indeed, bacteriologists and biometricians have met before, for example during debates over who should be "the final arbiter of medical knowledge" (clinicians, biometricans or bacteriologists) which influenced the disputes between the British biometrical school (Karl Pearson) and the bacteriologist Sir Almoth Wright over the effectiveness of Wright's antityphoid inoculation. ${ }^{12}$ This was the first time bacteriologists knew or appreciated the importance of counting their subjects. On an international scale, the statistical approach to food hygiene standards was becoming codified and institutionalized, and the role of players such as the FAO, WHO and others described below showcases this shift in approach to preventing foodborne illness.

This Codex initiative followed on the heels of similarly-minded groups which emerged during the same post-WWII period, such as in 1947 the International Organization for Standardization (ISO) based out of Geneva, and its subgroup ISO-TC34, based out of Hungary, which was starting to investigate standard methods for microbial testing and identification of salmonella. $^{13}$

The International Committee for Microbial Safety in Foods (ICMSF) (of which Dr. Betty Hobbs was a member) emerged in 1962 - the same year as the Codex 
Alimentarius. It was a standing committee of the International Association of Microbiological Societies (IAMS), which was divided into three broad sections: bacteriology, virology and mycology. ${ }^{14}$ The WHO would provide grants to the IAMS and its subsidiary bodies for expert advice. ${ }^{15}$ The International Committee for the Microbial Safety for Food consisted of 22 members from 15 countries, selected on the basis of their "technical competence and interest rather than as national representatives." $" 16$

Meanwhile, the young European Economic Community (EEC) was also focused on establishing directives, but in these early years aimed more at agricultural targets, as its Scientific Committee on Food was only established in 1974. For example, in 1973 the EEC produced some directives urging member states to adopt standard hygiene practices aimed at farmers and the poultry industry. ${ }^{17}$

For the Codex, however, the motivation behind many of its standards was the securing of developing countries' exports for reasons of both safety and the assurance of increased trade. When the Codex Europaeus (its regional predecessor group) linked up with the international Codex in the early 1960s, much of the tension around the decision to join forces was due to the issue of protecting both health and trade. These diverse interests had to be taken into account when constructing the hygiene standards, not just the health and trade aspects, but also the numerical inputs, statistical evidence, qualitative descriptions and behavioural practices that went into the finalized drafts sent to governments. Although statistics as a discipline and the use of statistical evidence in biomedical contexts had emerged earlier, the globalization of statistical techniques was helped along by the UN agencies: by the WHO through its monitoring and surveillance of global incidence of diseases like smallpox or malaria, and the FAO with its counting and surveying of the worldwide food supply and emphasis on nutritional data. ${ }^{18},{ }^{19}$ 
The conflict between the FAO and the WHO researchers was due in part to the identity of the different communities developing these standards. In a broader sense, statistical evidence (or as Porter says, "numbers, graphs and formulas" is also a strategy of communication that can "conveniently summarize a multitude of complex events and transactions [and behaviours]. "20 Moreover, a quantitative approach can be a "technology of distance" and the means by which "science has been constructed as a global network". ${ }^{21}$ A quantitative approach in the international food hygiene context would also mean different roles and expertise required for public health and food safety. In light of what statistical methods can represent, then, and given the intended goals and reach of the international Codex standards, quantitative approaches were seemingly a good match for the food hygiene standards work. Ultimately the qualitative approach to food hygiene was not completely eclipsed by a quantitative method, however; instead, the discussion fostered the blending of two outlooks and resulted in the refining notions of risk and how to measure it.

\section{THE CODEX COMMITTEE ON FOOD HYGIENE}

The Codex Committee on Food Hygiene (CCFH) was of great interest to the WHO due to its implications for public health. Chaired by the Government of the United States, members included delegates from: Australia, Canada, Cuba, Denmark, Ireland, Italy, the Netherlands, Poland, Portugal, Sweden, Switzerland, Turkey, the United Kingdom, along with representatives from various international organizations. Most were scientists ranging from food technologists, veterinary inspectors, medical inspectors, directors of laboratories for foodborne zoonoses, professors of food hygiene and environmental sanitation, and many were also representatives from member states' ministries of hygiene, health or agriculture. Its secretariat was particularly active in 
arranging tours of processing plants and meat packaging facilities, along with distributing reports, information and the draft hygiene standards to countries, industries or members who requested them.

The first meeting of the CCFH was held in Washington DC in 1964 at the Pan American Health Organization/WHO Building where it remained for the next several years, under the chairmanship of the Government of the United States. The Chairman was Lavega Robert (Bob) Shelton, a Bacteriologist working in the Division of Microbiology at the United States Food and Drug Administration.

The focus of the CCFH was not solely on the final product; rather, they described the entire process of food production, including methods, practices and behaviours. The standards, once fully elaborated, were thick documents giving the definition, storage requirements, plant and operational facilities, and 'end product description' (Figure 3).The end product description was for the product that would go on the market so that it is ready for human consumption; this would be a mainly qualitative description. Some of the CCFH end product specifications were slightly more specific, but emphasized the same basic message that the final object should be clean and free from harmful bits, as loosely defined (see Boxes $1 \& 2$ for examples).

Box 2: Canned Fruit and Vegetable End Product Specification. From: Food and Agriculture Organization, Report of the Fourth Session of the Codex Committee on Food Hygiene, Appendix III. Washington, D.C., 1967.

"To the extent possible in good manufacturing practice the product should be free from objectionable matter including insects and insect parts, insect webbing, soil, sand, or stone fragments, faecal matter of any kind, human or animal hair, and free from fungal filaments (mold) to an extent indicative of decayed ingredients; The product should be free from any pathogen infectious to man and from any toxic substance originating from bacteria or fungi; Products with an equilibrium $\mathrm{pH}$ above 4.5 should have received a processing treatment sufficient to destroy all spores of Clostridium botulinium, unless growth of surviving spores would be permanently prevented by product characteristics other than $\mathrm{pH} . "$ 
The CCFH had been developing standards like these for a few years focussing on descriptive requirements and standard operating procedures, and also detailing hygienic steps to be taken at the processing or manufacturing stages of the food supply chain. By the mid-1960s, however, some controversies arose among some members of the CCFH and with the WHO particularly with regard to attempting to standardize behaviours or hygienic practices, rather than just the final food object for human consumption. Moreover, a second key debate emerged over determining microbial counts in the final food product, and which sampling methods to employ, such as a statistical approach to microbial counts. The WHO increasingly insisted upon the input of biometricians and highlighted the role of biometricians in changing the shape of food safety and even went so far as to create its own expert food hygiene group independent of the Codex. Thus the work of the $\mathrm{CCFH}$ started to pose a problem for the push to establish international hygiene standards because it attempted to standardize behaviours and practices which would combat hygiene problems at all points along the food chain, rather than quantify microbial counts and methods of sampling that focused on the final (end) product.

\section{CODES OF HYGIENIC PRACTICE}

By the end of the 1960s, a "feeling of doubt and trouble" began to emerge in different countries and circles over accepting standards in the Codex Alimentarius - whether to adopt the standards for the final food object or the "Code of Principles" which one had to follow to produce a food object in a hygienic manner. ${ }^{22}$ One of these circles included the International Dairy Federation (the IDF) a powerful industry lobby group based out of Belgium with an interest in hygiene standards for milk and milk products. 
The trouble was that Codex standards were intended - and according to its statutes mandatory - for adoption among member states, and the onus would be on them to integrate the standards into their respective national legislation governing matters of public health and agriculture.

This was not the first time that Codes of Practice were attempted; about a decade earlier in 1956 the WHO and FAO joined forces as a joint "Committee of Government Experts" to establish a Code of Principles on Milk and Milk Products, governing such matters as methods of sampling and methods for the determination of fat contents or acidity in fluid and dried milks. This teamwork was one of the key inspirations to expand the international food standards program into the broader Codex. ${ }^{23}$ The IDF had worked closely with the two agencies (WHO and FAO) on these earlier principles, and it was recognized that the principles could not be mandatory, but instead provide guidance to those in "warm weather countries" and those at a "low stage of technical development." This milk team argued that:

"One of the major problems faced by the Committee stems from the wide variety of local situations in the world. While the same general principles are basic to dairy hygiene the world over, the methods by which these principles are to be applied must vary greatly from one country to another. This is particularly true with respect to those countries which are in the early stages of developing a milk programme, and where the nutritional needs of the population require the production and salvaging of as much milk as possible. Under primitive conditions, it is difficult if not impossible to apply the hygienic practices which are utilized in the more highly-developed countries." 24

The work of the CCFH was under scrutiny because it had come to the attention of the IDF and the larger Commission "that some of its subsidiary bodies were considering the 
elaboration, or were in fact elaborating, "international codes of practice" rather than standards." 25 A code of practice dealt with matters which were not strictly specifications or requirements for the foods themselves, (e.g. definition of terms, guiding principles, lists of commercial units), and their integration into national legislation would pose challenges to individual governments. Legislating international behaviours (for example, the wearing of hair nets, or gloves, on the abbatoir killing floor, or banning chewing gum in the kitchen) presents obvious problems for monitoring and enforcing these behaviours. And moreover, the cost of implementing recommended infrastructure (like stainless steel countertops, or elaborate irrigation systems on farms) was costly for member states, and impossible for some developing countries.

There were broader consequences for trade as well: For example, by 1969 U.K. veterinary inspectors had advised the U.K. not to accept meat from Paraguay, Uruguay and Northern Argentina, complaining that its refrigeration transport containers ("frigorificas") were not up to par, admitting that the "whole subject in the UK is a mixture of animal health, hygiene from the human health point of view and certainly domestic politics." 26 This "mixture" was also causing "headaches" for Australia, as the U.S Inspectors were also starting to question its meat handling practices.

Attempting to lay down "internationally acceptable" basic hygiene requirements was thus an attempt at a "common understanding" yet the FAO recognized that in this field there would "always be an area of judgment which can only be exercised by qualified veterinarians." 27 At the same time, however, and perhaps adding to the complexity of standardizing hygiene practices, the "purchaser" will always have the "last word". What the Codex hoped for was a common understanding at least between importer and exporter, but the CCFH kept running into problems, as hygiene practices were needed along the entire food production chain. In many cases member states would have to anticipate such contingencies, and, 
"provisions were needed which would deal with hygiene practices all along the course which the initial raw material has to follow in order to become a food for final consumption. Such hygiene aspects would cover all aspects of the handling of the raw material - be it the growing or harvesting of fish on board fishing vessels - the process and manufacturing of the raw material and the transportation and storage as well as the distribution of the final product."28

Because it was obvious that "a standard could not exhaustively provide for all contingencies which would cause a food either to become the carrier or the origin of a disease" the complaint from the IDF called into question the first 10 years of the Codex work.

To solve this problem, the legal counsels of both the WHO and the FAO were brought in for advice, and it was recommended that the Codes of principles or "Codes of Hygienic practice" developed by the CCFH and any other subsidiary bodies should be called advisory rather than 'mandatory' standards (see Box 3). The key factor was to ensure that the Codex work did not conflict with its two overarching goals of protecting consumer health and ensuring fair practices in the food trade. Stripping down the codes of hygienic practice like this to an advisory status, also meant reducing both the workload and the effectiveness of the CCFH. It was at this same time that the WHO also began to exert its authority and enlist the support of biometricians in making the standards more quantitative in nature.

Box 3: Example of a "Code of Practice" for Fresh Fruits and Vegetables. (From: Food and Agriculture Organization, Code of Hygienic Practice for Fresh Fruits and Vegetables, CAC/RCP 53-2003, FAO, Rome, Section 3.2.3.4., p.5.

\section{“3.2.3.4 Personal behaviour}

Agricultural workers should refrain from behaviour which could result in the contamination of food, for example: smoking, spitting, chewing gum or eating, or sneezing or coughing over unprotected fresh fruits and vegetables.

Personal effects such as jewellery, watches, or other items should not be worn or brought into fresh fruit and vegetable production areas if they pose a threat to the safety and suitability of the food." 


\section{THE BIOMETRICIANS}

One of the key developments around this time, was the increasing role of biometricians (as they were called) in shaping the food safety standards, especially the work of the International Commission on Microbial Specifications for Food(ICMSF) which the WHO was increasingly coming to rely upon for technical advice. ${ }^{29}$ The Co-Chairs of the ICMSF were Canadian microbiologists, Drs. Fred Thatcher and David Clarke, based out of the Department of Health and Welfare's Food and Drug Directorate in Ottawa. Other members were from the Netherlands, such as Dr. David Mossel (a Dutch expert on food microbiology) as well as Dr. Betty Hobbs. At a time when few women were working as microbiologists, Hobbs produced an influential series of books aimed not only at microbiologists but also at those working in the food service industry and for those preparing food in the home. These included Food Poisoning and Food Hygiene (1953) and Hygienic Food Handling (1962).

In May of 1969, the ICMSF met in Dubrovnik, and for the first time, their invited guests included biometricians. The ICMSF had convened before, but on this occasion they required the assistance of experts trained in statistical methods. Thatcher, its co-chair, announced to his colleagues how their "biometrican friends" deserved thanks for developing and explaining statistical sampling plans to the microbiologists. ${ }^{30}$ With a biometrical approach to microbes, the ICMSF began to exert great influence on the science of food hygiene. The CCFH's approach to food hygiene standards was from a more qualitative perspective, providing descriptions in lieu of numerical values such as microbial counts for food products. With the emergence of the ICMSF, however, and the advent of new statistical sampling techniques for microogranisms like Salmonella, the $\mathrm{CCFH}$ - at first reluctantly - had to incorporate the expertise of biometricians into their work, as the WHO, who worked much more closely with the international 
microbiologists than the FAO, insisted along with the ICMSF upon the input of biometricians and highlighted their role in changing the shape of food safety.

Collectively, the ICMSF produced a monograph and series of volumes on microorganisms in foods and how to count them, which became very influential worldwide and adopted in universities for teaching purposes. ${ }^{31}$ The first edition of Microorganisms in Foods: their significance and methods of enumeration (1968) identified the main culprits of food poisoning (Salmonella, Escherichia coli, Clostridium, Staphylococcus) and the methods and reagents needed to detect, isolate and analyze them. The second edition, however, was to be revised based on decisions made in Dubrovnik.

Even before this meeting the ICMSF decided that:

“Assuming some agreement on 'standards' the committee will again meet with the biometricans. If sampling plans have been recommended, these will be referred to the biometricians for comment; if not, then appropriate data and proposals for 'standards' will be offered to the biometricians and their advice sought." 32

The sampling plans themselves were very detailed and relied upon concepts of sample size, probability, population estimates, the use of lots and batches and coding systems, and the value "c": the maximum allowable number of microbes found in a product. These numerical values were specific to the microbe and specific to the food product (e.g. for salmonella, "c" had to be relatively lower, if not " 0 " depending upon the food it is found in). ${ }^{33}$ (See Figure 4.)

The increased reliance upon biometrical approaches to microbial food issues clashed with the standards set by the Codex food hygiene committee, mainly over the question of what was 'scientifically correct.' Despite the Codex being a joint FAO/WHO initiative, the WHO and went so far as to create its own expert food hygiene group 
independent of the Codex, and worked more closely with the ICMSF and thus with the biometricians, which brought an onslaught of confusion. As one member of the Codex wrote: "The argument over the functions of the Codex Committee on Food Hygiene and the [WHO] Expert Committee on Food Hygiene respectively seems to be going round in circles." 34 The WHO had greater interest in pathogens and in methods of sampling, whereas the Codex seemed to focus more broadly on the products themselves and approached their standards with a broader meaning of hygiene, not limited strictly to microbes, and also not relying upon numerical definitions.

This debate was occurring at time when the idea of taking a systems approach to food by monitoring the relative risks along a production chain - was gaining more currency. In the early 1960s, the United States Nautical and Space Association (NASA) had enlisted the help of the Pillsbury food company to create its Hazard Analysis Criticial Control Point (HACCP) system for space missions. ${ }^{35}$ HACCP applied engineering principles of "Critical Control Points" to food systems in order to gauge the hazard levels at various points in the food supply continuum, for example, in the abbatoir postslaughter, in the processing plant pre-packaging. ${ }^{36,37}$

The sampling plans put forward by the ICMSF were connected to this overall shift in microbial food safety, marked by a blending of qualitative with more quantitative approaches to food hygiene. It marked a shift where the meaning of safety became contested: the mere presence or absence of a microbe in a product did not make it (respectively) unsafe or safe as before. Instead, the application of a statistical approach to food hygiene meant that varying degrees of safety or risk could be assessed and expressed numerically. 


\section{"NOT SCIENTIFICALLY CORRECT"}

Dr. Ždenek Matyás admitted that the sampling plans were "a very controversial issue" at the time of development. And, when the question of uniting the two food hygiene groups arose, Matyás reported that when he "spoke privately at the [Codex] sessions in Washington with some of the recognized microbiologists present, they were against such closer relationships, saying that there are many other international committees or commissions working in the same field as International Commission on Microbial Specifications for Foodand which have also excellent results." 38

The Chairman of the Codex Food Hygiene group, Bob Shelton, wrote to his liaison officer in Rome:

"The question of Codex / ICMSF relations has always been intriguing to me. As a food microbiologist by training and experience, I am very sympathetic to the aims of the ICMSF and appreciative of the problems with which the group is wrestling. The method testing program and the studies on statistical design for sampling are splendid - no other group is in a position to take on such work. The individual members are experts in the field and I have high regard for each of them. Consequently, in my opinion, it is entirely logical to depend heavily on their expertise in food microbiology. For some reason which I never been able to fathom, there seems to be a deep antipathy toward the ICMSF on the part of Australia (Mr. Smith) and the U.K. (Dr. Ross). It is my understanding that these gentlemen were the principle antagonists to the liaison proposed at the second session of the Food Hygiene Committee. I believe we have our work cut out for us to achieve a good working relationship!"39 
Part of the problem was the involvement of the WHO with the outside groups and their failure (at least in the eyes of some of the FAO delegates) to communicate the information to the CCFH. Indeed, as the Australian committee member Ivan Smith aptly complained, "I find it somewhat surprising that one of the Governing Bodies [The W.H.O.] should be engaged in the elaboration of microbiological specifications for food with I.C.M.S.F. while the Codex subsidiary whose terms of reference encompass all aspects of food hygiene, is uniformed of the nature of that work." 40

One FDA observer to the Codex food Hygiene meetings noted how: "I have dropped by the Hygiene Committee meeting this week. These hygienists are difficult to please. Both McNally and Shelton have to work hard in order to move them past any controversial point."

But beyond administrative and communication complaints, the main sticking point appeared to be over the two different food hygiene approaches, on the one hand pursuing the raw material throughout its journey, and on the other, defining the microbial counts in the final product, items which would go on the market ready for consumption. The crux of the issue was a phrase that appeared in most of the Codex Group's standards for the final product: “...that products should be free from any pathogen infectious to man and from any toxic substance originating from microorganisms". ${ }^{41}$ The ICMSF strongly urged that simply describing the final product as "free from pathogens" was not enough; there had to be more rigorous numerical standards and methods for sampling. The WHO's position was that simple descriptive qualitative hygiene standards were "not scientifically correct". In a report describing the role of the food hygiene laboratory, they explained:

"The food hygiene laboratory can only give the microbial status of the food in relation to the sensitivity of the test used and with the consideration that tests 
can be used only for a limited range of pathogenic organisms. Further, the finding of no pathogens does not mean that such pathogens are absent from the food. They may not be found by the methods used. This caution is especially important since any other interpretation of microbiological data would lead to the impression that foods certified by a laboratory as pathogen-free did not contain pathogens, or might be so safe that subsequent care in handling could be disregarded. In order to maintain the scientific integrity of the food hygiene laboratory, the Committee recommends that no microbiological results be issued without a qualifying statement which indicates the exact number of samples examined in relation to the total lot in question, the quantity of sample, and the methods used." 42

The WHO warning above does not entirely rule out vigilance at other points along the food chain, as it suggested that 'subsequent care' was still necessary to ensure safe food. It clearly, however, supported the notion of sampling plans and the statistical approach. But, what was at stake by endorsing statistical evidence? By pairing the language of 'scientific correctness' with the sampling plans, the WHO was implicitly linking scientific with statistical evidence (and thereby making qualitative descriptions a subordinate form of evidence). Given the international reach of the UN agencies, this specific application of a quantitative risk assessment to food marks a period in which debates about the type of evidence upon which food hygiene standards should be based reaches a global level. ${ }^{43}$ This debate over the balance of quantitative and qualitative evidence is still occurring in food safety circles - particularly regarding the nature of risk and how to assess risk in food. The HACCP system has been "controversial" as it is a "semi-quantitative" in its approach to microbial food safety. ${ }^{44}$ Food safety experts have recently labelled qualitative measures to be "non-transparent", whereas quantitative evidence, in the form of risk assessments similar to that being described 
here by the WHO and the ICMSF, has become synonymous with "transparent" evidence. ${ }^{45}$ This discussion over qualitative and quantitative measures for food safety standards, and their implications for industry and public health, appears to be rooted in the 1960s hygiene debates of the Codex.

By 1973, methods for salmonella isolation for eggs and egg products were of particular concern and a growing problem, and at this point another international group, the International Organization for Standardization, or ISO, wrote to the Codex to notify them of its interest in developing Salmonella standards. This made for a total of three groups of international experts all attempting to draft microbiological food hygiene standards. Within days of this news, Bob Shelton, a bacteriologist from the FDA, submitted his resignation as the Codex hygiene chairman citing how it was evidently a time for "new ideas" in food hygiene. ${ }^{46}$ Announcing his resignation, he wrote: "While I am a staunch advocate that continuity of membership is desirable for the work of Codex Committees, I believe length of service by the Chairman can be carried to extremes. There is a risk of becoming fixed in ideas and this could be damaging to the work of the Committee." ${ }^{27}$

His replacement as Chair of the Codex Committee, Dr. Joseph C. Olson, worked with the U.S. Food and Drug Administration and was also a member of the International Committee for the Microbial Specifications for Food and with this connection, he was well-prepared to tackle the question of salmonella standards for egg and egg products. At this stage, all groups were prepared to embark upon inter-laboratory testing of methods of detection of salmonellae in egg and egg products and attempt to settle on salmonella testing standards. Olson wrote to a colleague about the ISO, Codex and ICMSF attempts to collaborate: 


\begin{abstract}
"We must recognize that microbiological methodology is in a dynamic state, and probably always will be. Unanimity of agreement of what is the best method is perhaps too much to ask. Undoubtedly some compromise will be necessary to reach a position that the Committee can be comfortable with." 48
\end{abstract}

Interestingly, then, once this shift had occurred in adopting statistical methods then it was more acceptable in the eyes of the international community to standardize practices such as laboratory methodologies for isolating salmonella. This domain was easier for controlling and collaboration purposes, even if "matching laboratories became more important than matching nature." ${ }^{49}$ Indeed, Salmonella became a sort of microbial "poster-child" for studies in microbial standardization: many articles and studies on how to control and test for this pathogen appeared in public health and medical journals during this time. ${ }^{50,51,52,53}$

\title{
CONCLUSION
}

This is not a simplistic story of one approach reigning triumphantly over the other; this debate remains ongoing today and a qualitative approach to food safety system management was never completely replaced by a quantitative one. Qualitative aspects are retained in the HACCP system which was endorsed by the ICMSF in the 1980s ${ }^{54}$ and also by the Codex Alimentarius in 1993, which gave HACCP worldwide currency as it spread as one of the most recognized and effective tools for food safety management. ${ }^{55}, 56$ The governance and management of food safety standards at the international level has only increased in complexity, however: although the origins of our modern global system of standards might be traced back to early groups such as the 
Codex, ISO and ICMSF, many national and international standard schemes have developed, some which are merely variations on the same theme, and many of which attempt to translate these standards into useable formats for various sectors of industry, be it SMEs, retail or catering or for on-farm management.

This is neither a story of one standard triumphing over the other, however. Although the ICMSF remains a leading voice in the application of statistical sampling plans to food hygiene, the practicality of these sampling plans for application beyond the laboratory by inspectors or to the so called "farm-to-fork" continuum by food handlers remains questionable 40 years on as they are still "not fully understood" particularly in relation to other risk management approaches such as HACCP or Food Safety Objectives. ${ }^{57}$

Instead, in the wake of this historical debate and the subsequent globalization of food standards, the burden of practicality has shifted more toward industry and national public health departments of member states to find ways to integrate and make these standards more manageable and applicable to various contexts along the food production chain, and to find a blend of quantitative and qualitative ways of assessing and managing risks. For example, the Consumer Goods Forum, an independent global parity-based Consumer Goods network, has established the Global Food Safety Initiative (GFSI) in 2000 which attempts to ensure equivalence between the various standards and auditing schemes to be used as benchmarks globally. On a national level, the U.K. Food Standards Agency has established schemes such as Safer Food Better Business (SFBB) aimed at the catering and retail sector.

This conflict between the FAO and WHO expert groups may represent a variation on a common theme since conflicts between experts, as Smith and Phillips have argued, seem so "widespread in food policy making and regulation that they might fairly be 
described as endemic." ${ }^{, 58}$ It is problematic to say that one approach or the other was victorious in the global food safety system: this early clash of two approaches to food hygiene, marked by the rise of statistical applications toward microbiology, and the WHO's urge to shift away from focusing on standardizing human behaviour to the food product instead represents once again how the Codex standards shows (and future work on food safety management necessitates) a co-production of diverse elements. It is clearly necessary to find the common ground if we are to develop best practice approaches to food safety management.

\section{ACKNOWLEDGEMENTS}

Thanks Lucia Dacome for comments on this paper. Many thanks also to the archival team at the Food and Agriculture Organization Headquarters in Rome for assistance in locating the correspondence from the earliest days of the Codex. This work was supported by funding from the Canadian Social Sciences and Humanities Research Council (SSHRC).

\section{CONFLICTS OF INTEREST}

None. 


\section{FIGURES}

Figure 1: Habits to Avoid. From Hobbs, Food Poisoning and Food Hygiene (1953).

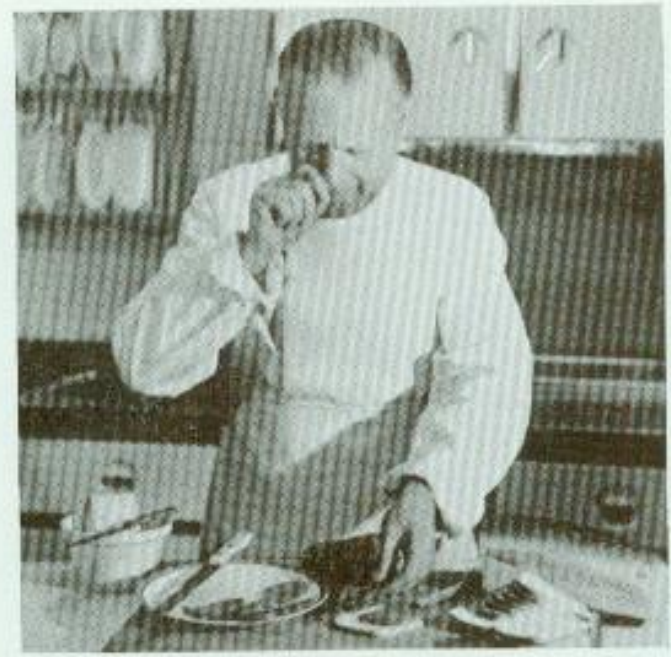

Fio. 24. Habits to avoid - fingering the nose while preparing sandwiches 
Figure 2. Human salmonellosis and its possible sources. From Hobbs, Food Poisoning and Fnad Hugiono 1052

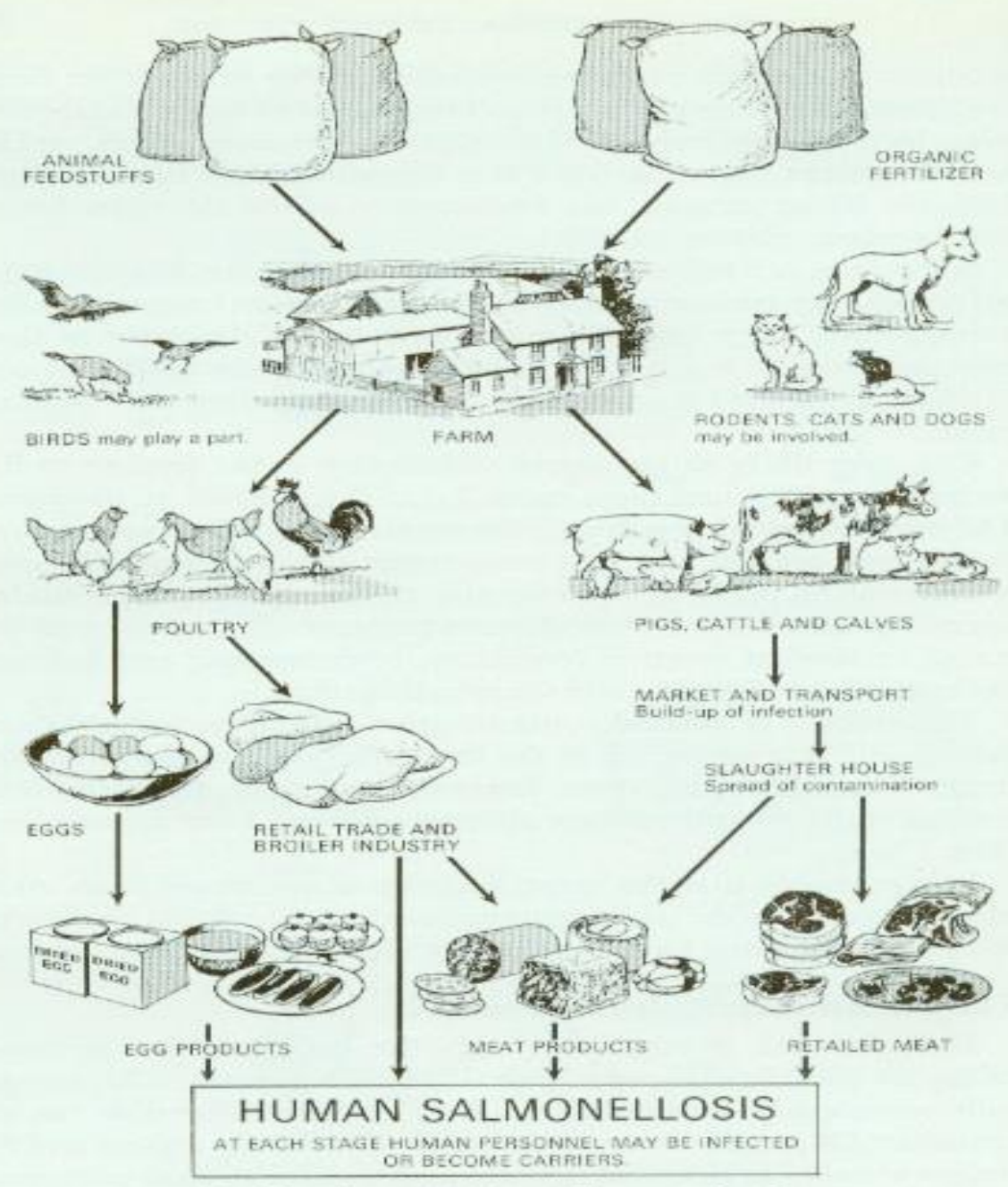

Fia. 17. Spread of salmonella contamination

PREVENTIVE MEASURES TVCTUDE:

1. Improved hygiene of production in country of origin, an farrns, in markets, slaughter-bouses and in factories.

2. Treatment of foods liable to contamination including human and animal foodstuffs by pasteurization, dry heat, irradiation and other methods. 
Figure 3. To Kill a Chicken. Standardized poultry killing recommendations From Food and Agriculture Organization, Report of the Sixth Session of the Codex Committee on Fond Hvoiono Mav 1060

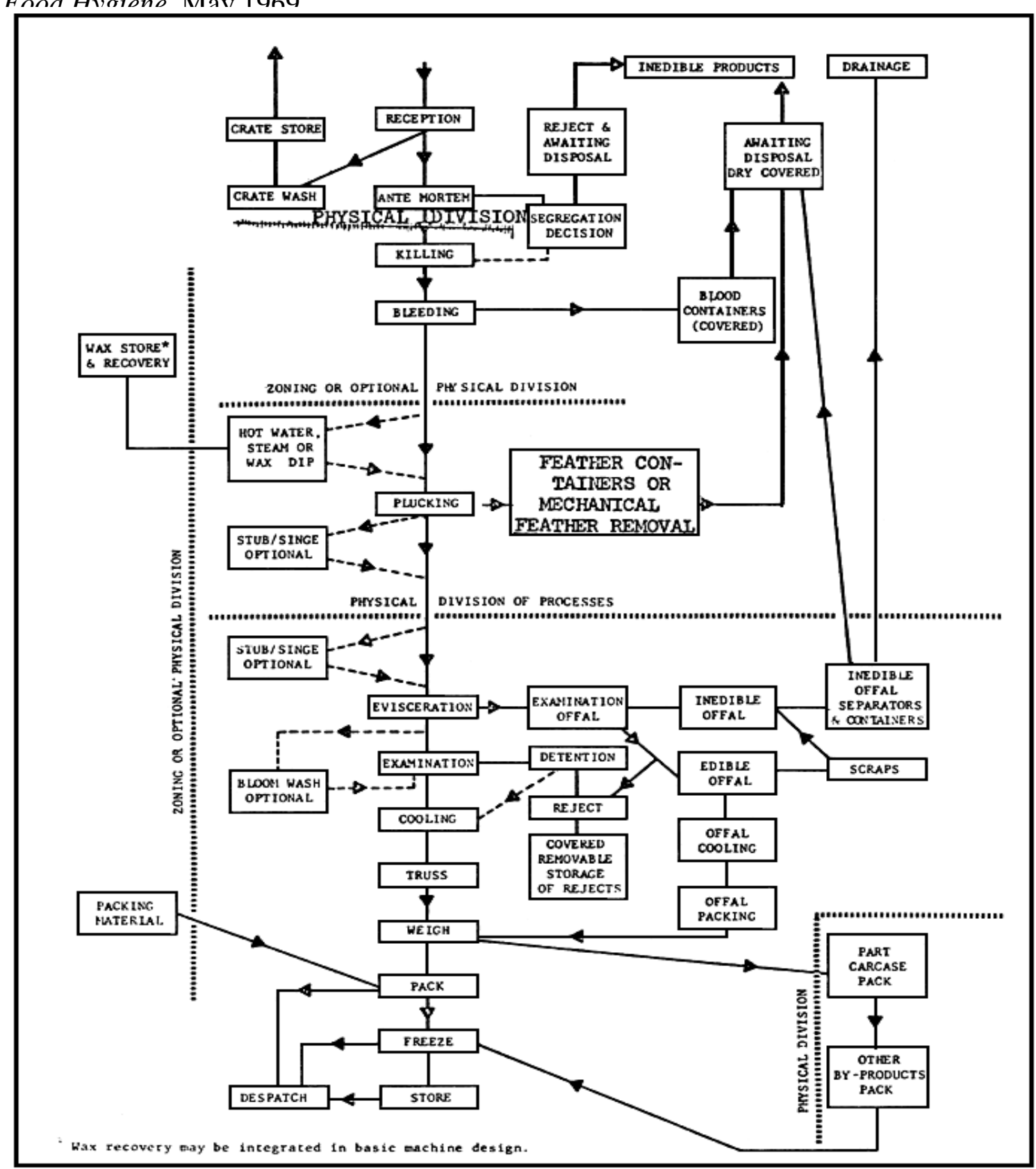


Figure 4. Sampling plans and recommended microbiological limits for dried foods: ingredients known to present microbiological hazards. From: Thatcher and Clark (eds.) Microorganisms in Foods: their significance and methods of enumeration, 2nd Edition, Toronto, University of Toronto Press, 1978.

TABLE 21

Sampling plans and rccommended microbiological limits for dried foods; ingredients known to present microbiological hazards

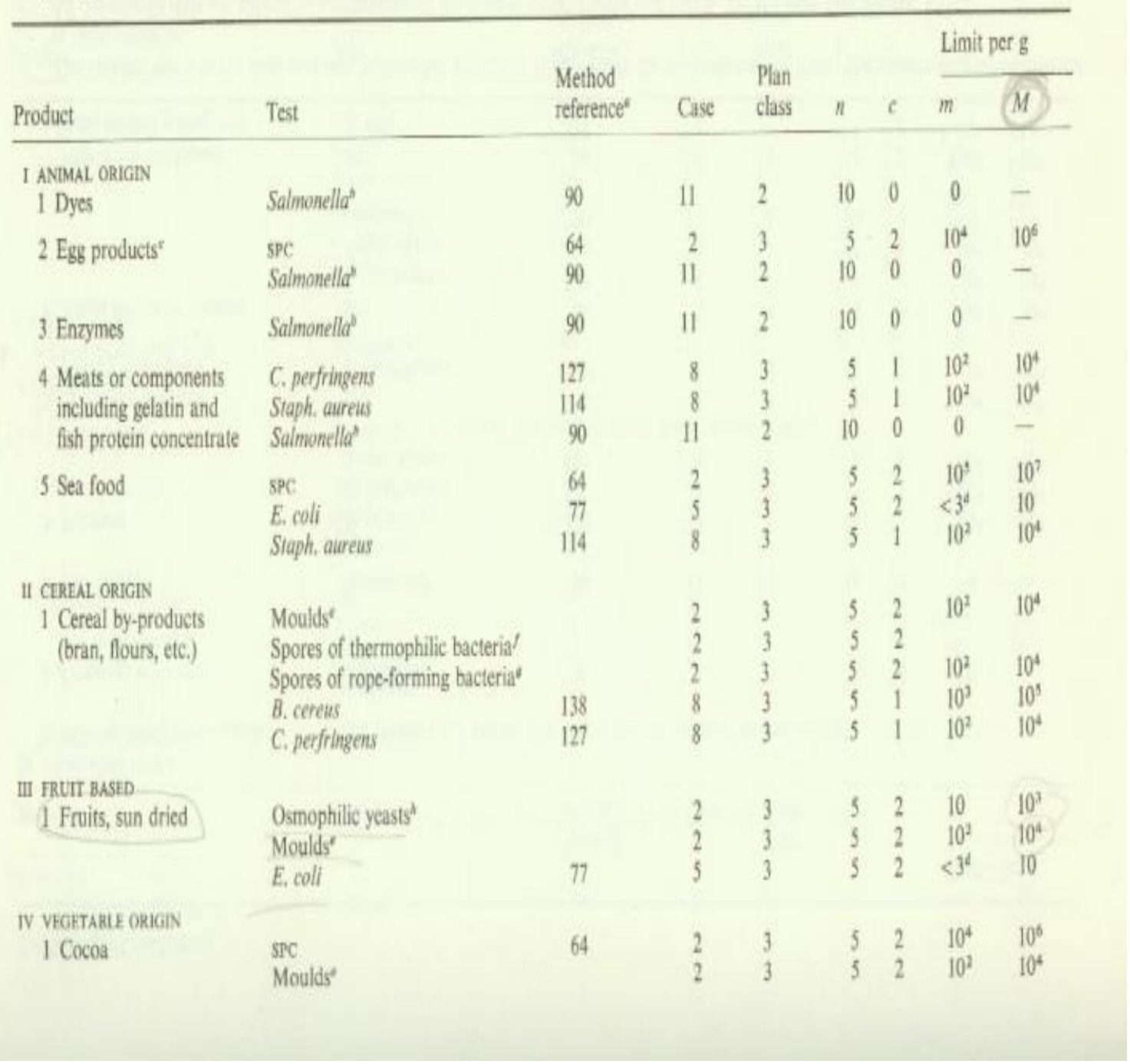


TABLE 21 (Concluded)

\begin{tabular}{|c|c|c|c|c|c|c|c|c|}
\hline \multirow[b]{2}{*}{ Product } & \multirow[b]{2}{*}{ Test } & \multirow{2}{*}{$\begin{array}{l}\text { Method } \\
\text { reference" }\end{array}$} & \multirow[b]{2}{*}{ Case } & \multirow{2}{*}{$\begin{array}{l}\text { Plan } \\
\text { class }\end{array}$} & \multirow[b]{2}{*}{ n } & \multirow[b]{2}{*}{$c$} & \multicolumn{2}{|c|}{ Limit per $g$} \\
\hline & & & & & & & $m$ & M \\
\hline \multirow[t]{3}{*}{2 Coconut } & \multirow{3}{*}{$\begin{array}{l}\text { Moulds' } \\
\text { Coliforms or } \\
\text { Enterobacteriaceae } \\
\text { Salmonella }\end{array}$} & & 2 & 3 & 5 & 2 & $10^{2}$ & $10^{4}$ \\
\hline & & $\begin{array}{l}77 \\
82\end{array}$ & 5 & 3 & 5 & 2 & 10 & $10^{3}$ \\
\hline & & 90 & 15 & 2 & 60 & 0 & 0 & - \\
\hline 3 Dyes & SPC: & 64 & 2 & 3 & 5 & 2 & $10^{4}$ & $10^{\circ}$ \\
\hline 4 Enzymes & E. coll & 77 & 5 & 3 & 5 & 2 & $<3^{e}$ & 10 \\
\hline \multirow[t]{2}{*}{5 Gums } & \multirow{2}{*}{$\begin{array}{l}\text { SPC } \\
\text { Coliforms or } \\
\text { Enterobacteriaceac }\end{array}$} & 64 & 2 & 3 & 5 & 2 & $10^{4}$ & $10^{t}$ \\
\hline & & $\begin{array}{l}69 \\
82\end{array}$ & 5 & 3 & 5 & 2 & 10 & $10^{3}$ \\
\hline \multirow[t]{2}{*}{6 Nuts } & Moulds & & 2 & 3 & 5 & 2 & $10^{2}$ & $10^{4}$ \\
\hline & E. coll & 77 & 5 & 3 & 5 & 2 & $<3^{n}$ & 10 \\
\hline \multirow[t]{3}{*}{7 Spices } & SPC & 64 & 2 & 3 & 5 & 2 & $10^{4}$ & $10^{6}$ \\
\hline & Moulds? & & $\frac{2}{5}$ & 3 & 5 & 2 & $\begin{array}{l}10^{2} \\
10\end{array}$ & $\begin{array}{l}10^{4} \\
10^{3}\end{array}$ \\
\hline & E. coli & $\pi$ & 3 & 3 & 3 & 2 & & \\
\hline \multirow[t]{2}{*}{8 Yeasts } & $\begin{array}{l}\text { E. coli } \\
\text { Solmomellas }\end{array}$ & 77 & $\begin{array}{r}5 \\
11\end{array}$ & 3 & $\begin{array}{r}5 \\
10\end{array}$ & 2 & $<3_{0}^{i}$ & 10 \\
\hline & Sarmonetia & 90 & 11 & 2 & & & & \\
\hline 9 Vegetables & $\begin{array}{l}\text { E. coll } \\
\text { Salmonella }\end{array}$ & $\begin{array}{l}77 \\
90\end{array}$ & $\begin{array}{r}5 \\
11\end{array}$ & $\begin{array}{l}3 \\
2\end{array}$ & $\begin{array}{r}5 \\
10\end{array}$ & 2 & $\begin{array}{c}<3^{a} \\
0\end{array}$ & $\begin{array}{l}10^{2} \\
-\end{array}$ \\
\hline
\end{tabular}

a This column refers to the page numbers in Thatcher and Clark (1968) where the methods are described. Use sample sizes recommended in these methods.

b All Saimonella tests are subject to compositing of the sample units (Silliker and Gabis, 1973; Gabis and Silliker, 1974).

$c$ These plans do not apply to egg albumin desugared by bacterial fermentation.

$d$ ' $<$ ' 3 means no positive tube in the standard 3-tube MPN technique.

$\ell$ The method of Mossel et al, (1970) is suggested.

$f$ The method of the National Canners' Association of the us (National Canners Association, 1968) is recommended.

$g$ The method recommended by Sharf et al. (1964) is suggested.

it The method of Mossel \& Bax (1967) is suggested. 


\section{REFERENCES}

${ }^{1}$ Hobbs, BC. Food Poisoning and Food Hygiene. London: Central Public Health Laboratory,1953.

${ }^{2}$ Jasanoff, S. States of Knowledge: The Co-Production of Science and Social Order. New York:

Routledge, 2004, p. 3.

${ }^{3}$ Hardy, A. Food, Hygiene and the Laboratory. A Short History of Food Poisoning in Britain circa 18501950. Soc Hist Med. 1999; 12(2): 293-311.

${ }^{4}$ Hardy, A. Food, Hygiene and the Laboratory. A Short History of Food Poisoning in Britain circa 18501950. Soc Hist Med. 1999; 12(2): 293-311.

${ }^{5}$ Hardy, A. Food, Hygiene and the Laboratory. A Short History of Food Poisoning in Britain circa 18501950. Soc Hist Med. 1999; 12(2): 293-311.

${ }^{6}$ Nestle, M. Safe Food: Bacteria, Biotechnology and Bioterrorism. Berkeley: University of California Press, 2003, p. 1.

${ }^{7}$ Thoms, U. Between promise and threat: Antibiotics in Foods in Germany 1950-1980.

NTM Zeitschrift für Geschichte der Wissenschaften, Technik und Medizin. 2012; 20(3):181-214.

${ }^{8}$ Hamilton, S. The Economies and Conveniences of Modern-Day Living: Frozen Foods and Mass

Marketing, 1945-1965. Bus Hist Rev. 2003; 77 (1): 33-60.

${ }^{9}$ Hacking, I. The Taming of Chance. Cambridge: Cambridge University Press, 1990.

${ }^{10}$ Porter, T. The Rise of Statistical Thinking, 1820-1900. Princeton, NJ: Princeton University Press, 1986.

${ }^{11}$ Porter, T. Trust in Numbers: the Pursuit of Objectivity in Science and Public Life. Princeton, N.J.:

Princeton University Press, 1995.

${ }^{12}$ Matthews, RJ. Quantification and the Quest for Medical Certainty. Princeton, N.J.: Princeton

University Press, 1995, p. 100.

${ }^{13}$ Joint FAO/WHO Food Standards Programme Codex Alimentarius Commission. Report of the Ninth

Session of the Codex Committee on Food Hygiene. Washington, D.C., U.S.A. 19-23 June 1972.

${ }^{14}$ Sand, P. Legal Officer, WHO, Letter to WL de Haas, 28 January 1972. The Food and Agricultuer Organization Archives, Rome.

${ }^{15}$ Crane, PH. FAO Staff, Letter to Kermode, GO, Chief of the Food Standards Program, 31 January 1972. CX 4/20 The Food and Agriculture Organization Archives, Rome.

${ }^{16}$ Joint FAO/WHO Food Standards Programme Codex Alimentarius Commission. Report of the Ninth Session of the Codex Committee on Food Hygiene. Washington, D.C., U.S.A. 19-23 June 1972.

${ }^{17}$ Our View: EEC poultry directive - Unreasonable and unnecessary? Frozen Foods August/September 1973. The Food and Agriculture Organization Archives, Rome.

${ }^{18}$ Borowy, I. Maneuvering for Space: International Health Work of the League of Nations during World War II. In: Solomon SG, Murard L and Zylberman P (eds) Shifting Boundaries of Public Health: Europe in the Twentieth Century. Rochester Studies in Medical History Series, Brown TB (ed). Rochester: University of Rochester Press, 2008, pp. 104-105.

${ }^{19}$ Ilcan S. and Phillips L. Making food count: expert knowledge and global technologies of government. Canadian review of sociology and anthropology. 2003; 40(4): 441-461.

${ }^{20}$ Porter, TM. Trust in Numbers: the Pursuit of Objectivity in Science and Public Life. 1995. Princeton, N.J.: Princeton University Press, ix.

${ }^{21}$ Porter, TM. Trust in Numbers: the Pursuit of Objectivity in Science and Public Life. 1995. Princeton, N.J.: Princeton University Press, ix.

${ }^{22}$ Servais, J. Chief Engineer-Director of the Ministry of Agriculture, Bruxelles, Belgium, Letter to Dr. Kesteven, Chief Animal Industry Branch, FAO, 4 July 1968. CX 4/20 Vol. III Box 12Cx12 Food and Agriculture Organization, Archives, Rome. 
${ }^{23}$ Saint-Pol, G. Legal Counsel FAO, Letter to Mr. G.O. Kermode 22 November 1968. Cx 4/20 Vol. I. Box 12C x 12. The Food and Agriculture Organization Archives, Rome.

${ }^{24}$ World Health Organization. Second Report of the Joint FAO/WHO Expert Committee on Milk Hygiene. 29 July 1959. World Health Organization Archives, Geneva.

${ }^{25}$ Joint FAO/WHO Food Standards Programme. Codes of Practice in Relation to the Codex Alimentarius. Sixth Session, Geneva, 4-14 March 1969. CX 4/20 Vol. I. Box 12 C x 12. The Food and Agriculture Organization Archives, Rome.

${ }^{26}$ Kermode, GO. Chief of the FAO/WHO Programme, Food Standards Branch, Letter to O. Wells, Director-General of the FAO, 13 June 1969. CX4/20. Vol. I. Box 12 C x 12. The Food and Agriculture Organization Archives, Rome.

${ }^{27}$ Kermode GO Letter to O. Wells, 13 June 1969. CX4/20. Vol. I. Box 12 C x 12. The Food and Agriculture Organization Archives, Rome.

${ }^{28}$ Joint FAO/WHO Food Standards Programme. Codes of Practice in Relation to the Codex Alimentarius. Sixth Session, Geneva, 4-14 March 1969. CX4/20. Vol. I. Box 12 C x 12. The Food and Agriculture Organization Archives, Rome.

${ }^{29}$ Matyas, Z. WHO Food Hygienist, letter to FS Thatcher, Co-Chair of ICMSF, 28 January 1969. CX4/20. Vol. I. Box 12 C x 12. The Food and Agriculture Organization Archives, Rome.

${ }^{30}$ FS Thatcher, Co-Chair of ICMSF, Letter to the International Committee on Microbiological Specifications for Foods, January 13, 1969. CX4/20. Vol. I. Box 12 C x 12. The Food and Agriculture Organization, Rome.

${ }^{31}$ FS Thatcher, Co-Chair of the ICSMF, Letter to the International Committee on Microbiological Specifications for Foods, January 13, 1969. CX4/20. Vol. I. Box 12 C x 12. The Food and Agriculture Organization Archives, Rome.

${ }^{32}$ FS Thatcher, Letter to the International Committee on Microbiological Specifications for Foods, January 13, 1969. CX4/20. Vol. I. Box 12 C x 12. The Food and Agriculture Organization Archives, Rome.

${ }^{33}$ Thatcher, FS and Clarke, DS, International Commission for the Microbial Specifications for Foods. Microorganisms in Foods: Sampling for microbial analysis: Principles and specific applications. Volume 2. Toronto, Buffalo, London: University of Toronto Press, 1974, pp. 100-101.

${ }^{34}$ Götzsche, NO. Letter to F. Winkelmann, Dairy Branch FAO, April 10, 1968. CX4/20. Vol. I. Box 12 C $\mathrm{x}$ 12. The Food and Agriculture Organization Archives, Rome.

${ }^{35}$ Ross-Nazzal, J. From farm to fork: How space food standards impacted the food industry and changed food safety standards. In: SJ Dick and Launius RD (eds) Societal impact of spaceflight. Washington: National aeronautics and Space administration, Office of External RelationsHistory Division, 2007. (NaSa Sp-2007-4801). http://history.nasa.gov/sp4801-part1.pdf [accessed Feb 2014].

${ }^{36}$ Sperder, WH and Stier RF. Happy 50th Birthday to HACCP: Retrospective and Prospective. Food Safety magazine. 2009/2010 (42): 44-46.

${ }^{37}$ Wallace, CA and Mortimore SE. HACCP A practical approach, Third edition. London, Dordrecht, Heidelberg, New York: Springer, 2013.

${ }^{38}$ Zdenek Matyas, Z. WHO Food Hygienist Letter to G Kermode, 27 March 1972. CX4/20.Vol. II. Box $12 \mathrm{C} x$ 12. The Food and Agriculture Organization Archives, Rome.

${ }^{39}$ Shelton, B. Chairman of the Codex Food Hygiene Committee (CCFH), Letter to W de Haas, Secretary of the CCFH, February 9, 1972, CX4/20. Vol. II. Box 12 C x 12. The Food and Agriculture Organization Archives, Rome. 
${ }^{40}$ Smith IH, CCFH Member from Australia (Department of Primary Industry), Letter to G Kermode, Chief, Food Standards Branch, Joint Food Standards Program of the FAO/WHO, 6 January 1972. CX4/20. Vol.II. Box 12 C x 12. The Food and Agriculture Organization Archives, Rome.

${ }^{41}$ Food and Agriculture Organization of the United Nations. Report of the Fifth Session of the Codex Committee on Food Hygiene, Washington, D.C., p. 4.

42 "The Role of the Food Hygiene Laboratory in Food Hygiene Programs" Report of the WHO Expert Committee on Microbiological Aspects of Food Hygiene, Geneva, October 1967. CX4/20. Vol. I. Box 12 $\mathrm{C} x$ 12. The Food and Agriculture Organization Archives, Rome.

${ }^{43}$ Buchanan, RL. Understanding and Managing Food Safety Risks. Food Safety Magazine [Internet]. 2010/ 2011 [Accessed February 2014]. Available from: http://www.foodsafetymagazine.com/article.asp?id=3882\&sub=sub1.

${ }^{44}$ Buchanan, RL. Understanding and Managing Food Safety Risks. Food Safety Magazine [Internet]. 2010/ 2011 [Accessed February 2014]. Available from: http://www.foodsafetymagazine.com/article.asp?id=3882\&sub=sub1.

${ }^{45}$ Buchanan, RL. Understanding and Managing Food Safety Risks. Food Safety Magazine [Internet]. 2010/ 2011 [Accessed February 2014]. Available from:

http://www.foodsafetymagazine.com/article.asp?id=3882\&sub=sub1.

${ }^{46}$ Shelton B, Chairman of the CCFH Letter to W de Haas, Secretary of the CCFH. Sept 6, 1973, CX4/20. Vol. III. Box 12 C x 12. The Food and Agriculture Organization Archives, Rome.

${ }^{47}$ Shelton B. Chairman of the CCFH and USFDA Letter to William de Haas, CCFH Secretary, Sept 6, 1973. CX4/20. Vol. III. Box 12 C x 12. The Food and Agriculture Organization Archives, Rome.

${ }^{48}$ Olson, JC. Chairman of the CCFH and USFDA staff member, Letter to Dr. K. Buchli, Public Health Officer, Ministry of Public Health, the Netherlands, November 12, 1973. CX4/20. Vol. III. Box 12 C x 12. The Food and Agriculture Organization Archives, Rome.

${ }^{49}$ Pieters, A. Managing differences in biomedical research: The case of standardizing Interferons. Studies in History and Philosophy of Biological and Biomedical Sciences. 29 (1998): 31-79.

${ }^{50}$ Edel, W and Kampelmacher, EH. Comparative Studies on Salmonella-isolation in Eight European Laboratories. Bulletin of the World Health Organization, 196839 (3): 487-491.

${ }^{51}$ Edel, W and Kampelmacher, EH. Salmonella Isolation in Nine European Laboratories Using a Standardized Technnique. Bulletin of the World Health Organization, 196941 (2): 297-308.

${ }^{52}$ Roberts, D, Boag, K, Hall MLM and Shipp, CR. The Isolation of Salmonellas from British Pork Sausages and Sausage Meat. The Journal of Hygiene, 1975; 75( 2): 173-184.

${ }^{53}$ Williams, L. and Newell, KW. Salmonella excretion in joy riding pigs. American Journal of Public Health, 1970; 60(5): 926-929.

${ }^{54}$ ICMSF. Microorganisms in Foods 4: Application of the Hazard Analysis Critical Control Point (HACCP) System to Ensure Microbiological Safety and Quality. 1988. Oxford: Blackwell Scientific Publications, 1988.

${ }^{55}$ Codex Committee on Food Hygiene. Guidelines for the Application of the Hazard Analysis Critical Control Point (HACCP) System. In: Training Considerations for the Application of the HACCP System to Food Processing and Manufacturing, WHO/FNU/FOS/93.3 II. Geneva: World Health Organization, 1993.

${ }^{56}$ Wallace, CA, Sperber, WH and Mortimore, SE. Food Safety for the $21^{\text {st }}$ Century: Managing HACCP and Food Safety Throughout the Global Supply Chain. Oxford: Wiley-Blackwell, 2011, p. 8.

57 Dahms, S. Microbiological sampling plans -Statistical aspects. Mitt. Lebensm. Hyg. 2004; 95: 32-44.

${ }^{58}$ Smith DF and Phillips, J. Food policy and regulation: a mulitiplicity of actors and experts. In: Smith DF and Phillips J. (eds) Food, Science, Policy and Regulation in the Twentieth Century: International and Comparative Perspectives. New York and London: Routledge, 2000, p. 8. 